\title{
Design, Synthesis and Biological Evaluation of Novel Class Diindolyl Methanes (DIMs) Derived from Naturally Occurring Phenolic Monoterpenoids
}

\author{
Jamatsing D Rajput, Suresh D Bagul, Samina K Tadavi, Pravin S Karandikar and Ratnamala S Bendre*
}

School of Chemical Sciences, North Maharashtra University, Jalgaon, Maharashtra, India

\begin{abstract}
Several Diindolyl alkanes and their derivatives have been isolated from plant and marine sources. Among the various derivatives of indoles, Diindolyl methanes have wide medicinal applications such as to induce apoptosis in human cancer cells, antibacterial, Anti-inflammatory, antiviral and hormonal control activities. Therefore, they play essential role in marine as well as terrestrial living systems. In present studies we report novel class of Diindolyl methanes prepared from natural phenolic monoterpenoids, via ortho formylation of phenolic monoterpenoids (Carvacrol, Thymol and Eugenol), followed by synthesis, characterization, anticancer, antioxidant and $\alpha$-amylase inhibitory activities. All the synthesized derivatives show moderate anticancer activities against human breast cell line $\mathrm{MCF}_{7}$, good antioxidant and $\alpha$-amylase inhibitory activities using DPPH and $\alpha$-amylase assay respectively.
\end{abstract}

Keywords: Carvacrol; Thymol; Eugenol; DIM; $\alpha$-Amylase; DPPH; SRB

\section{Introduction}

The Diindolyl methanes (DIMs) are a class of alkaloids that includes fundamental framework of two indol-3-yl groups bridged by single methyl group and they are differentiated by the substituents attached to the bridging methyl carbon [1]. Commonly most DIMs are found in both marine and terrestrial organisms; a few of them are reported exclusively from either terrestrial or marine organisms. First DIMs derivatives were isolated from genotoxic metabolite of human intestinal bacteria Streptococcus faecium, [2] (Streptindol; Figure 1). Later on number of naturally occurring analogs of DIMs were isolated and reported Some of the naturally occurring Di(Diindolyl)methane derivatives [3] are depicted in Figure 1. Moreover, there are number of reports on synthetic derivatives of DIMs $[4,5]$. Due to excellent bioefficacy of Diindolyl methanes, large number of reports are available in literature, [6-9] on their synthesis; most of these methods involve treatment of indoles with aldehydes in presence of homogeneous acid catalysts or lewis acids and only few reports are based on the use of heterogeneous catalysts [10-12]. Recently some organic chemists have made an effort for development of a hazard-free, waste-free and energy-efficient synthetic route and it may be of great use for economical synthesis of this class of compounds [13]. In persistence to our efforts towards development of efficient synthetic methodologies for preparation of biologically significant scaffolds; herein we have developed an efficient procedure for preparation of new class of Diindolyl methanes and performed their biological activities.

Carvacrol, Thymol, and Eugenol are found in essential oils of many plants $[14,15]$. These three naturally occurring phenolic monoterpenoids are outstanding resourceful molecules incorporated as useful ingredients in various products and have found applications in pharmaceutical, agricultural, fragrance, flavour, cosmetic and various other industries $[16,17]$. There huge range of pharmacological activities including antimicrobial, anti-inflammatory, analgesic, anti-oxidant and anticancer activities have been well-researched $[18,19]$. We synthesized ortho formyl phenolic monoterpenoids using Reimer-Tiemann Reaction [20] and constructed a new series of Diindolyl methanes using ortho formyl derivatives carvacrol, thymol and eugenol.

In the present work, we report a simple synthetic method for the synthesis of new class of Diindolyl methane derivatives in the presence of $\mathrm{SnCl}_{4}, \mathrm{AlCl}_{3}$ and citric acid as catalysts in ethanol as solvent at ambient temperature and investigated the biological activities of these synthesized derivatives.

\section{Results and Bioassay}

\section{Reaction scheme}<smiles>[R]c1c([R])c([R])c(O)c([R])c1[R]</smiles>

$\mathrm{R}_{1}=\mathrm{CH}_{3}, \mathrm{R}_{2=} \mathrm{H}, \mathrm{R}_{3}=\mathrm{H}$ and $\mathrm{R}_{4}=\mathrm{CH}\left(\mathrm{CH}_{3}\right)_{2}$ then Carvacrol.

$\mathrm{R}_{1}=\mathrm{CH}\left(\mathrm{CH}_{3}\right)_{2}, \mathrm{R}_{2=} \mathrm{H}, \mathrm{R}_{3}=\mathrm{H}$ and $\mathrm{R}_{4}=\mathrm{CH}_{3}$ then Thymol.

$\mathrm{R}_{1}=\mathrm{OCH}_{3}, \mathrm{R}_{2=} \mathrm{H}, \mathrm{R}_{3}=$ allyl and $\mathrm{R}_{4}=\mathrm{H}$ then Eugenol.

Scheme 1: Reaction protocol for the synthesis of ortho formylation of phenolic monoterpenoids.

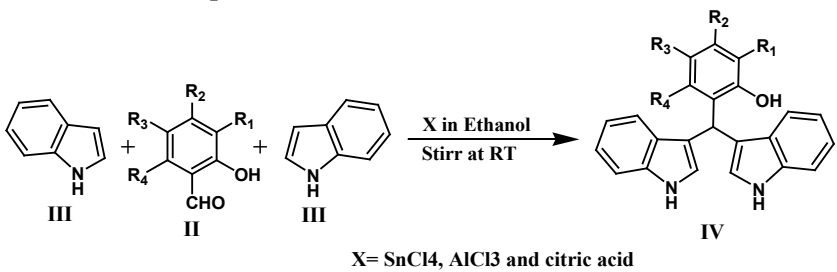

$\mathrm{R}_{1}=\mathrm{CH}_{3}, \mathrm{R}_{2=} \mathrm{H}, \mathrm{R}_{3}=\mathrm{H}$ and $\mathrm{R}_{4}=\mathrm{CH}\left(\mathrm{CH}_{3}\right)_{2}$ then Carvacryl Diindolyl methane (CDI).

*Corresponding author: Prof. (Mrs.) Ratnamala S. Bendre, Head, Department of Pesticides and Agrochemical, School of Chemical Sciences, North Maharashtra University, Jalgaon-425 001, Maharashtra, India, E-mail: bendrers@rediffmail.com

Received February 03, 2016; Accepted February 19, 2016; Published February 23, 2016

Citation: Rajput JD, Bagul SD, Tadavi SK, Karandikar PS, Bendre RS (2016) Design, Synthesis and Biological Evaluation of Novel Class Diindolyl Methanes (DIMs) Derived from Naturally Occurring Phenolic Monoterpenoids. Med chem (Los Angeles) 6: 123-128. doi:10.4172/2161-0444.1000336

Copyright: $\odot 2016$ Rajput JD, et al. This is an open-access article distributed under the terms of the Creative Commons Attribution License, which permits unrestricted use, distribution, and reproduction in any medium, provided the original author and source are credited. 
Citation: Rajput JD, Bagul SD, Tadavi SK, Karandikar PS, Bendre RS (2016) Design, Synthesis and Biological Evaluation of Novel Class Diindolyl Methanes (DIMs) Derived from Naturally Occurring Phenolic Monoterpenoids. Med chem (Los Angeles) 6: 123-128. doi:10.4172/21610444.1000336

$\mathrm{R}_{1}=\mathrm{CH}\left(\mathrm{CH}_{3}\right)_{2}, \mathrm{R}_{2=} \mathrm{H}, \mathrm{R}_{3}=\mathrm{H}$ and $\mathrm{R}_{4}=\mathrm{CH}_{3}$ then Thymyl Diindolyl methane (TDI).

$\mathrm{R}_{1}=\mathrm{OCH}_{3}, \mathrm{R}_{2=} \mathrm{H}, \mathrm{R}_{3}=$ allyl and $\mathrm{R}_{4}=\mathrm{H}$ then Eugenyl Diindolyl methane (EDI).

Scheme 2: Reaction protocol for synthesis of Diindolyl methane derivatives.

\section{Anticancer activity}

In vitro anticancer activities of compounds CBM, TBM and EBM were performed using Sulforhodamine B (SRB) assay on panel of human cancer cell line (MCF- 7) [21]. The cell lines were grown in RPMI 1640 medium containing 10\% fetal bovine serum and $2 \mathrm{mM}$ L-glutamine. For present screening experiment, cells were inoculated into 96 well microtiter plates in $90 \mu \mathrm{L}$ at 5000 cells per well. After cell inoculation, the microtiter plates were incubated at $37^{\circ} \mathrm{C}, 5 \% \mathrm{CO}_{2}, 95 \%$ air and $100 \%$ relative humidity for $24 \mathrm{~h}$ prior to addition of experimental drugs. Experimental drugs were solubilized in appropriate solvent to prepare stock of $10^{-2}$ concentration. At the time of experiment four 10fold serial dilutions were made using complete medium. Aliquots of $10 \mu \mathrm{l}$ of these different drug dilutions were added to the appropriate micro-titer wells already containing $90 \mu \mathrm{l}$ of medium, resulting in the required final drug concentrations. After addition of compound, plates were incubated at standard conditions for 48 hours and assay was terminated by the addition of cold TCA. Cells were fixed in situ by the gentle addition of $50 \mu \mathrm{l}$ of cold $30 \%(\mathrm{w} / \mathrm{v}$ ) TCA (final concentration, $10 \%$ TCA) and incubated for 60 minutes at $4^{\circ} \mathrm{C}$. The supernatant was discarded; the plates were washed five times with tap water and air dried. Sulforhodamine B (SRB) solution $(50 \mu \mathrm{l})$ at $0.4 \%(\mathrm{w} / \mathrm{v})$ in $1 \%$ acetic acid was added to each of the wells, and plates were incubated for 20 minutes at room temperature. After staining, unbound dye was recovered and the residual dye was removed by washing five times with $1 \%$ acetic acid. The plates were air dried. Bound stain was subsequently eluted with $10 \mathrm{mM}$ trizma base, and the absorbance was read on an Elisa plate reader at a wavelength of $540 \mathrm{~nm}$ with $690 \mathrm{~nm}$ reference wavelength (Table 1).

\begin{tabular}{|c|c|c|c|c|c|}
\hline Structure of DIM & Physical State & Catalyst & Yield & Reaction Condition & Solvent \\
\hline \multirow{4}{*}{ CDIMs } & \multirow[t]{4}{*}{ Solid } & $\mathrm{SnCl}_{4}(20 \%)$ & $\begin{array}{l}82 \% \\
85 \%\end{array}$ & $\mathrm{RT}=30 \mathrm{~min}$ Reflux $=10 \mathrm{~min}$ & Ethanol/ Methanol \\
\hline & & Citric acid $(20 \%)$ & $\begin{array}{l}74 \% \\
80 \%\end{array}$ & $\mathrm{RT}=30 \mathrm{~min}$ Reflux $=10 \mathrm{~min}$ & Ethanol/ Methanol \\
\hline & & $\mathrm{AlCl}_{3}(20 \%)$ & $\begin{array}{l}85 \% \\
85 \%\end{array}$ & $\mathrm{RT}=30 \mathrm{~min}$ Reflux $=10 \mathrm{~min}$ & Ethanol/ Methanol \\
\hline & & & & & \\
\hline \multirow[b]{3}{*}{ TDIMs } & \multirow[t]{3}{*}{ Solid } & $\mathrm{SnCl}_{4}(20 \%)$ & $\begin{array}{l}85 \% \\
90 \%\end{array}$ & $\mathrm{RT}=30 \mathrm{~min}$ Reflux $=10 \mathrm{~min}$ & Ethanol/ Methanol \\
\hline & & Citric acid $(20 \%)$ & $\begin{array}{l}80 \% \\
84 \%\end{array}$ & $\mathrm{RT}=30 \mathrm{~min}$ Reflux $=10 \mathrm{~min}$ & Ethanol/ Methanol \\
\hline & & $\mathrm{AlCl}_{3}(20 \%)$ & $\begin{array}{l}90 \% \\
90 \%\end{array}$ & $\mathrm{RT}=30 \min$ Reflux $=10 \mathrm{~min}$ & Ethanol/ Methanol \\
\hline & \multirow[t]{4}{*}{ Solid } & $\mathrm{SnCl}_{4}(20 \%)$ & $\begin{array}{l}80 \% \\
85 \%\end{array}$ & $\mathrm{RT}=30 \mathrm{~min}$ Reflux $=10 \mathrm{~min}$ & Ethanol/ Methanol \\
\hline & & Citric acid $(20 \%)$ & $\begin{array}{l}74 \% \\
80 \%\end{array}$ & $\mathrm{RT}=30 \mathrm{~min}$ Reflux $=10 \mathrm{~min}$ & Ethanol/ Methanol \\
\hline & & $\mathrm{AlCl}_{3}(20 \%)$ & $\begin{array}{l}85 \% \\
88 \%\end{array}$ & $\mathrm{RT}=30 \min$ Reflux $=10 \mathrm{~min}$ & Ethanol/ Methanol \\
\hline EDIMs & & & & & \\
\hline
\end{tabular}

The $\mathrm{GI}_{50}$ values, defined as the drug concentration required for Percent Growth and were expressed as the ratio of average absorbance of the test well to the average absorbance of the control wells $\times 100$. (C), and test growth in the presence of drug at the four concentration levels (Ti)], the percentage growth was calculated at each of the drug concentration levels.

All synthesized derivatives have been found to be active against human breast cancer cell $\mathrm{MCF}_{7}$ at higher concentration, with $\mathrm{GI}_{50}$ of Carvacryl Diindolyl methane (CDIM) $33.5 \mu$, Eugenyl Diindolyl methane (EDIM) as $84.8 \mu$ land Thymyl Diindolyl methane (TDIM) as $88.4 \mu \mathrm{l}$, it suggests that all the synthesized derivatives possess moderate anticancer activities against human breast cancer cell $\mathrm{MCF}_{7}$ (Figure 2).

\section{Antioxidant activity}

DPPH radical-scavenging activity was performed by the reported method [22]. For each determination, the stock solution $(1 \mathrm{mg} / \mathrm{ml})$ was diluted by serial dilution $(25 \mu \mathrm{g}-200 \mu \mathrm{g} / \mathrm{ml})$ with $60 \%$ (v/v) ethanol. An aliquot of each dilution $(0.5 \mathrm{~mL})$ was mixed with methanolic solution of DPPH $(5 \mathrm{~mL}, 0.06 \mathrm{mM})$. The mixtures were shaken vigorously and incubated at $37^{\circ} \mathrm{C}$ in the dark for $30 \mathrm{~min}$. At the same time, a control containing $60 \%(\mathrm{v} / \mathrm{v})$ ethanol $(0.5 \mathrm{~mL})$ and methanolic solution of DPPH $(5 \mathrm{~mL}, 0.06 \mathrm{mM})$ was run. The absorbance was measured at $517 \mathrm{~nm}$. The percentage of DPPH scavenging versus concentration of samples was plotted. The concentration of the sample necessary to decrease the DPPH concentration by $50 \%$ was obtained by interpolation from linear regression analysis and denoted as $\mathrm{IC}_{50}$ value $(\mu \mathrm{g} / \mathrm{mL})$. All determinations were carried out in triplicate. Ascorbic acid was used as reference compound.

In antioxidant activity performed by DPPH assay, all the synthesized derivatives exhibited good antioxidant activities at lower as well as higher concentrations. IC $_{50}$ of Carvacryl Diindolyl methane (CDIM) is $53.50 \pm 0.150 \mu \mathrm{g} / \mathrm{ml}$, Eugenyl Diindolyl methane (EDIM) is $56.22 \pm$ $0.142 \mu \mathrm{g} / \mathrm{ml}$, Thymyl Diindolyl methane (TDIM) is $58.44 \pm 0.150 \mu \mathrm{g} /$ inhibiting growth of cell proliferation by $50 \%$, were calculated from Using the six absorbance measurements [time zero (Tz), control growth

Table 1: Chemical structures, physical state, catalyst, reaction condition, solvent and yields. 
Citation: Rajput JD, Bagul SD, Tadavi SK, Karandikar PS, Bendre RS (2016) Design, Synthesis and Biological Evaluation of Novel Class Diindolyl Methanes (DIMs) Derived from Naturally Occurring Phenolic Monoterpenoids. Med chem (Los Angeles) 6: 123-128. doi:10.4172/21610444.1000336

$\mathrm{ml}$ and Ascorbic Acid (Std) is $44.33 \pm 0.167 \mu \mathrm{g} / \mathrm{ml}$. The results indicate that all the synthesized derivatives possess outstanding antioxidant activities (Figure 3).

\section{$\alpha$-Amylase inhibitory activity}

This assay was performed using reported modified 4 a-amylase inhibition assay, [23] total $250 \mu \mathrm{L}$ of solutions of compounds having various concentrations were placed in different hard glass tubes and 250 $\mu \mathrm{L}$ of $0.02 \mathrm{M}$ Sodium phosphate buffer ( $\mathrm{pH} 6.9$ ) containing $\alpha$-amylase solution was added to it. All the solutions were pre-incubated at $25^{\circ} \mathrm{C}$ for $10 \mathrm{~min}$, after which $250 \mu \mathrm{L}$ of $1 \%$ starch solution in $0.02 \mathrm{M}$ sodium phosphate buffer ( $\mathrm{pH}$ 6.9) was added at time intervals and then further incubated at $25^{\circ} \mathrm{C}$ for $10 \mathrm{~min}$. The reaction was termintaed by adding $500 \mu \mathrm{L}$ of Dinitrosalicylic acid (DNS) regent. The tubes were then incubated in boiling water for $5 \mathrm{~min}$ and cooled to room temperature. The reaction mixture was diluted with $5 \mathrm{ml}$ distilled water and the absorbance was measured at $540 \mathrm{~nm}$ using Spectrophotometer. A control was prepared using the same procedure replacing the compounds with water. Concentrations of samples resulting in $50 \%$ inhibition of enzyme activity $\left(\mathrm{IC}_{50}\right)$ were determined graphically.

All the synthesized derivatives show excellent $\alpha$-amylase inhibitory activity at lower to higher concentration. IC $_{50}$ of Thymyl Diindolyl methane (TDIM) is $56.48 \pm 0.123 \mu \mathrm{g} / \mathrm{ml}$, Eugenyl Diindolyl methane (EDIM) is $82.70 \pm 0.150 \mu \mathrm{g} / \mathrm{ml}$, Carvacryl Diindolyl methane (CDIM) is $110.18 \pm 0.145 \mu \mathrm{g} / \mathrm{ml}$ while that of Acarbose (Std) is $50.26 \pm 0.114$ $\mu \mathrm{g} / \mathrm{ml}$. Overall view of this activity suggested that Thymyl Diindolyl methane (TDIM) having $56.48 \pm 0.123 \mu \mathrm{g} / \mathrm{ml}$ is most potent to inhibit the $\alpha$-amylase (Figure 4 ).

\section{Experimental}

All the chemicals and reagents necessary for the reactions were procured from Sigma-Aldrich and Fisher scientific chemicals with purity $98 \%$ and used without further purification. The products were characterized using ${ }^{1} \mathrm{H}$ NMR, ${ }^{13} \mathrm{C}$ NMR spectra. NMR spectra of the products were obtained using Bruker AC- $400 \mathrm{MHz}$ spectrometers<smiles>CC(=O)OCC(c1c[nH]c2ccccc12)c1c[nH]c2ccccc12</smiles>

Streptindol<smiles>CC(c1c[nH]c2ccccc12)c1c[nH]c2ccccc12</smiles>

vibrindole $\mathrm{A}$<smiles>CCCC(=O)OCC(c1c[nH]c2ccccc12)c1c[nH]c2ccccc12</smiles>

Arsindoline B<smiles>c1ccc2c(C(c3c[nH]c4ccccc34)c3c[nH]c4ccccc34)c[nH]c2c1</smiles>

1,1,1-tris(3-indolyl)methane<smiles>c1ccc2c(Cc3c[nH]c4ccccc34)c[nH]c2c1</smiles>

Arundine<smiles>O=C1Nc2ccccc2C1(c1c[nH]c2ccccc12)c1c[nH]c2ccccc12</smiles>

Trisindoline<smiles>CC(CC(c1c[nH]c2ccccc12)c1c[nH]c2ccccc12)c1c[nH]c2ccccc12</smiles>

1,1,3-tris(3-indolyl)butane<smiles>c1ccc2c(C(c3c[nH]c4ccccc34)c3c[nH]c4ccccc34)ccnc2c1</smiles>

Arsindoline A

Figure 1: Naturally occurring Diindolyl Methanes (DIMs) Derivatives. 
Citation: Rajput JD, Bagul SD, Tadavi SK, Karandikar PS, Bendre RS (2016) Design, Synthesis and Biological Evaluation of Novel Class Diindolyl Methanes (DIMs) Derived from Naturally Occurring Phenolic Monoterpenoids. Med chem (Los Angeles) 6: 123-128. doi:10.4172/21610444.1000336

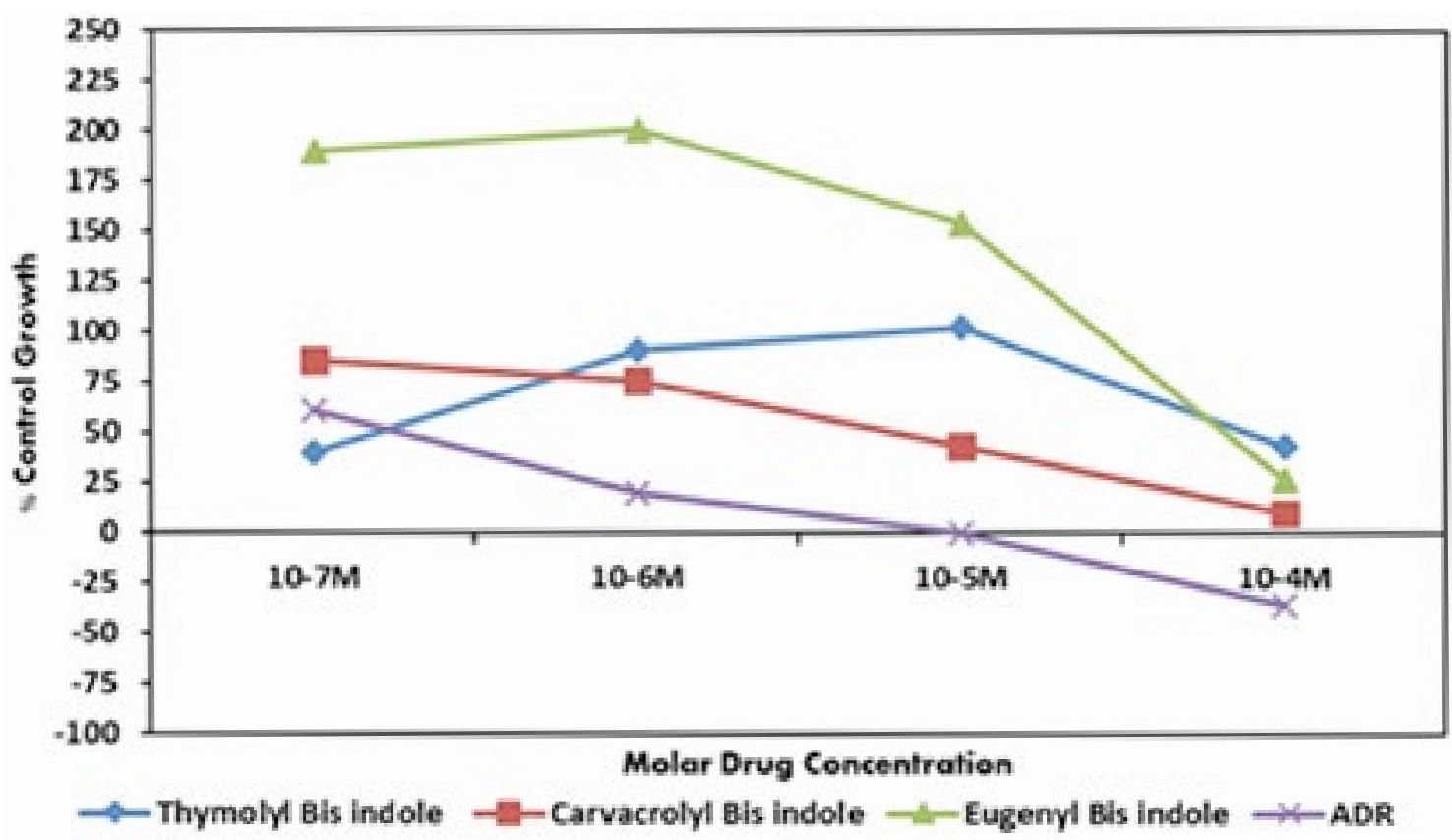

Figure 2: Graph shows anticancer activity of CBIM, TBIM and EBIM.

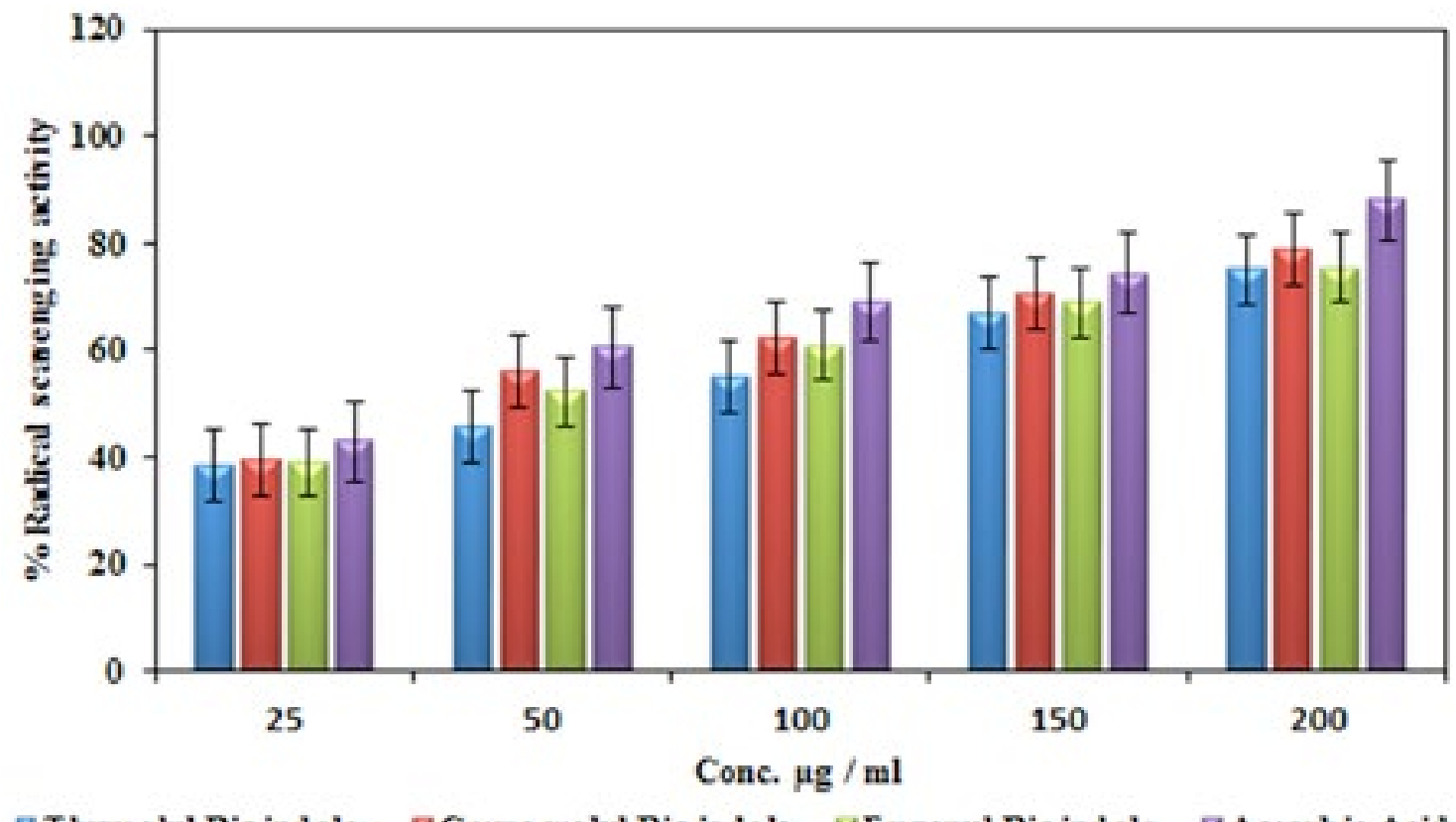

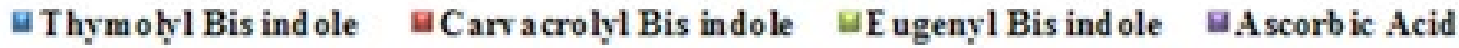

Figure 3: Graph indicating Antioxidant Activity of CBIM, TBIM and EBIM.

with TMS as the internal standard. Mass spectra of the products were obtained using LC-MS.

\section{Procedure for synthesis of ortho formylation on phenolic} monoterpenes

In round bottom flask fitted with a water reflux condenser and a thermometer; $\mathrm{NaOH}(6.66 \mathrm{~g}, 0.16 \mathrm{M})$ was placed and dissolved in
(7 $\mathrm{mL})$ distilled water and phenolic monoterpene $(0.02$ Mole $)$ was added to it. The temperature inside the flask was adjusted to $60-65^{\circ} \mathrm{C}$. Chloroform ( 0.04 Mole) was introduced in small portions with stirring by maintaining the temperature to $60-65^{\circ} \mathrm{C}$ during addition. The mixture was stirred for 2 hours. Excess of chloroform was removed by steam distillation from alkaline solution. The solution was allowed to cool and then it was acidified with dilute $\mathrm{HCl}(1 \%)$. The acidified solution was steam distilled until no more oily drops were collected. 
Citation: Rajput JD, Bagul SD, Tadavi SK, Karandikar PS, Bendre RS (2016) Design, Synthesis and Biological Evaluation of Novel Class Diindolyl Methanes (DIMs) Derived from Naturally Occurring Phenolic Monoterpenoids. Med chem (Los Angeles) 6: 123-128. doi:10.4172/21610444.1000336

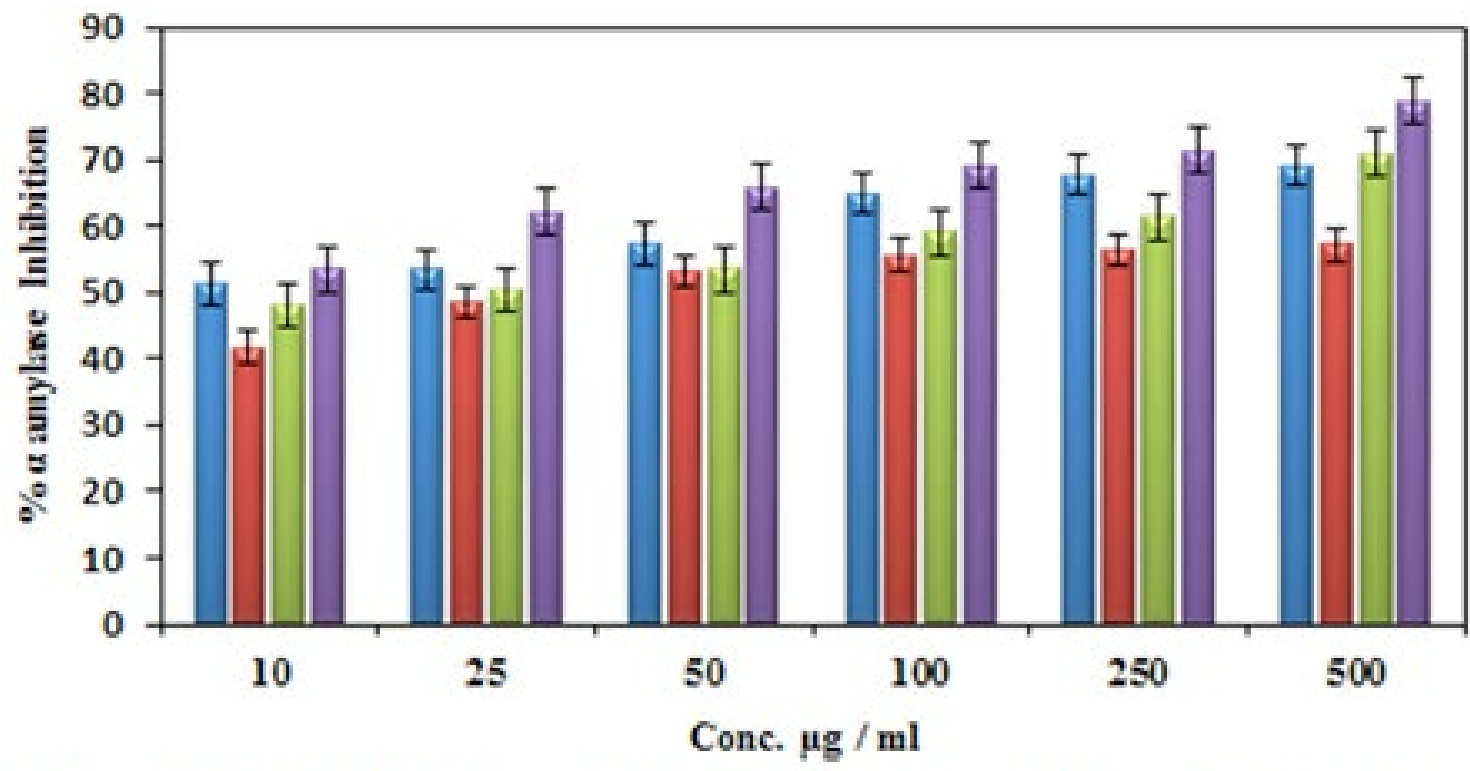

$\square$ Thymolyl Bis indole $₫ \mathrm{Carracrolyl} \mathrm{Bis} \mathrm{indole} \square \mathrm{E}$ ugenyl Bis ind ole $₫$ Acarbose

Figure 4: Graph shows $\alpha$-amylase inhibitory Activity of CBIM, TBIM and EBIM

The distillate was extracted with ether $(3 \times 30 \mathrm{~mL})$. Most of the ether was removed by distillation. The residue, which contains unreacted phenolic monoterpene and ortho formylated phenolic monoterpene, was transferred to a small glass stoppered flask and about twice the volume of saturated sodium metabisulphite solution was added to it. The solution was stirred vigoursly for $1 / 2 \mathrm{~h}$ and allowed to stand for $1 \mathrm{~h}$. The paste of bisulphite compound was filtered and washed with little ethanol and finally with little ether. The bisulphite compound was decomposed by warming in round bottom flask on a water bath with dilute $\mathrm{H}_{2} \mathrm{SO}_{4}$. The mixture was allowed to cool and then the ortho formylated phenolic monoterpene was extracted with ether $(3 \times 30 \mathrm{~mL})$. Removal of ether gave pure ortho formylated phenolic monoterpene. Finally all the three ortho formyl Phenolic monoterpenes were characterized by spectroscopic methods.

\section{Procedure for synthesis of Diindolyl methanes (DIMs)} derivatives from ortho formyl phenolic monoterpenes

A mixture of ortho formyl phenolic monoterpenes $(0.0756 \mathrm{~g}, 0.5$ mmol, 1 equiv.), indole $(0.1171 \mathrm{~g}, 1 \mathrm{mmol}, 2$ equivalent) and catalysts (i.e., $\mathrm{SnCl}_{4}, \mathrm{AlCl}_{3}$ and citric acid) $(10 \mathrm{mg})$ in ethanol $(3 \mathrm{~mL})$ was stirred vigorously at room temperature until the disappearance of the starting indole, checked by TLC (30 $\mathrm{min})$. When the reaction was completed, the reaction mixture was filtrated and washed with water. Then, the reaction mixture was concentrated under reduced pressure. The residue was purified by recrystallization using ethanol and water system (70:30).

Carvacryl Diindolylmethane (CDI): Color Light pink, $\mathrm{mp}-110^{\circ} \mathrm{C}$. IR (KBr): 3395, 3048, 2950, 2345, 1595, 1433, 750; ${ }^{1} \mathrm{H} \mathrm{NMR}\left(\mathrm{CDCl}_{3}\right) \delta$ $1.22(\mathrm{~d}, \mathrm{~J}=4.0 \mathrm{~Hz}, 6 \mathrm{H}), 2.09(\mathrm{~s}, 3 \mathrm{H}), 3.36-3.42(\mathrm{~m}, \mathrm{~J}=4.0 \mathrm{~Hz}, 1 \mathrm{H}), 6.28$ $(\mathrm{s}, 1 \mathrm{H}), 6.30(\mathrm{~d}, \mathrm{~J}=8.0 \mathrm{~Hz}, 1 \mathrm{H}), 6.71(\mathrm{~s}, 2 \mathrm{H}), 6.89(\mathrm{~d}, \mathrm{~J}=8.0 \mathrm{~Hz}, 1 \mathrm{H}), 6.70$ (d, J=8.0 Hz, 2H), 7.06 (s, 1H), 7.17 (dd, J=8.0 Hz, 1H), 7.23 (dd, J=8.0 $\mathrm{Hz}, 1 \mathrm{H}) 7.31$ (d, J=8.0 Hz, 2H), $7.33(\mathrm{~d}, \mathrm{~J}=8.0 \mathrm{~Hz}, 2 \mathrm{H}), 7.93(\mathrm{~s}, 2 \mathrm{H}) \cdot{ }^{13} \mathrm{C}$ NMR $16.09\left(\mathrm{CH}_{3}\right), 24.23\left(\mathrm{CH}_{3}\right), 29.52(\mathrm{CH}-\mathrm{Ar}), 32.62\left(\mathrm{CH}_{3}-\mathrm{Ar}\right), 111.37$ (CH Methane), 116.70 (Ar), 116.99 (Ar), 119.65(Ar), 119.89 (Ar),
122.44 (Ar), 123.01 (Ar), 124.11(Ar), 125.23 (Ar), 126.81 (Ar), 129.41 (Ar), 137.09 (Ar), 144.96 (Ar), 154.27 (Ar). LC-MS (methanol), m/z: $394.4[\mathrm{M}+\mathrm{H}]^{+}, 395.4[\mathrm{M}+1]^{+}$.

Thymyl Diindolylmethane (TDI): Color pink, mp- $102^{\circ} \mathrm{C}$. IR (KBr): 3395, 3048, 2950, 2345, 1595, 1433, 750; ${ }^{1} \mathrm{H}$ NMR $\left(\mathrm{CDCl}_{3}\right) \delta$ $1.13(\mathrm{~d}, \mathrm{~J}=4.0 \mathrm{~Hz}, 6 \mathrm{H}), 2.42$ (s, 3H), 3.08-3.15 (m, J=4.0 Hz, 1H), 6.13 $(\mathrm{s}, 1 \mathrm{H}),, 6.25(\mathrm{~d}, \mathrm{~J}=8.0 \mathrm{~Hz}, 1 \mathrm{H}), 6.72(\mathrm{~s}, 2 \mathrm{H}), 6.81(\mathrm{~d}, \mathrm{~J}=8.0 \mathrm{~Hz}, 1 \mathrm{H}), 6.83$ (d, J=8.0 Hz, 2H), 7.06 (s, 1H), 7.17 (dd, J=8.0 Hz, 1H), 7.21 (dd, J=8.0 $\mathrm{Hz}, 1 \mathrm{H}), 7.24(\mathrm{~d}, \mathrm{~J}=8.0 \mathrm{~Hz}, 2 \mathrm{H}), 7.32(\mathrm{~d}, \mathrm{~J}=8.0 \mathrm{~Hz}, 2 \mathrm{H}), 7.92(\mathrm{~s}, 2 \mathrm{H}) \cdot{ }^{13} \mathrm{C}$ NMR $20.50\left(\mathrm{CH}_{3}\right), 22.72\left(\mathrm{CH}_{3}\right), 26.37(\mathrm{CH}-\mathrm{Ar}), 33.68\left(\mathrm{CH}_{3}-\mathrm{Ar}\right), 111.33$ (CH Methane), 116.38 (Ar), 119.66 (Ar), 119.76 (Ar), 122.27 (Ar), 122.47 (Ar), 123.89 (Ar), 124.14 (Ar), 126.38 (Ar), 126.94 (Ar), 133.97 (Ar), 134.20 (Ar), 136.97 (Ar), 153.45 (Ar). LC-MS (methanol), m/z: $394.4[\mathrm{M}+\mathrm{H}]^{+}, 395.4[\mathrm{M}+1]^{+}$.

Eugenyl Diindolyl methane (EDI): Color red, $\mathrm{mp}-98^{\circ} \mathrm{C}$. IR $(\mathrm{KBr})$ : $3065,3413,3054,2496,1611,1428,924 ;{ }^{1} \mathrm{H}$ NMR $\left(\mathrm{CDCl}_{3}\right) \delta 3.11(\mathrm{~d}$, $\mathrm{J}=\mathrm{Hz}, 2 \mathrm{H}), 3.77$ (s, 3H), 4.90-4.94 (m, 2H), $5.69(\mathrm{~s}, 1 \mathrm{H}), 5.79-5.85(\mathrm{dd}$, $\mathrm{J}=\mathrm{Hz}, 1 \mathrm{H}), 6.21(\mathrm{~s}, 1 \mathrm{H}), 6.51(\mathrm{~d}, \mathrm{~J}=8.0 \mathrm{~Hz}, 2 \mathrm{H}), 6.53(\mathrm{~d}, \mathrm{~J}=8.0 \mathrm{~Hz}, 2 \mathrm{H})$, 6.93-6.97 (m, 2H), 7.06-7.10 (m, 2H), $7.18(\mathrm{~s}, 2 \mathrm{H}), 7.39(\mathrm{~d}, 1 \mathrm{H}), 7.41(\mathrm{~s}$, $1 \mathrm{H}), 7.58(\mathrm{~s}, 2 \mathrm{H}),{ }^{13} \mathrm{C}$ NMR $33.01\left(\mathrm{CH}_{2}-\mathrm{Ar}\right), 40.04\left(\mathrm{CH}_{3}-\mathrm{Ar}\right), 56.00$ (CH-Ar), $109.11\left(\mathrm{CH}_{2}=\right), 111.12$ (CH Methane), 115.30 (Ar), 118.77 (Ar), 119.13 (Ar), 120.06 (Ar), 121.82 (Ar), 122.09 (Ar), 123.62 (Ar), 127.23 (Ar), 129.45 (Ar), 130.73 (Ar), 136.74 (Ar), 138.26 (Ar), 141.43 (Ar), 146.49 (Ar). LC-MS (methanol), m/z: $407.3[\mathrm{M}+\mathrm{H}]^{+}$.

\section{Conclusion}

A new class of Diindolyl methanes (DIMs) derivatives have been synthesized and characterized by various spectroscopic methods. These derivative exhibited significant biological activities such as anticancer, antioxidant and $\alpha$-amylase inhibitory activity. All the synthesized derivatives are active against human breast cancer cell line $\mathrm{MCF}_{7}$ at higher concentration, similarly wonderful antioxidant and $\alpha$-amylase inhibitory activities have been observed at every concentration. In 
Citation: Rajput JD, Bagul SD, Tadavi SK, Karandikar PS, Bendre RS (2016) Design, Synthesis and Biological Evaluation of Novel Class Diindolyl Methanes (DIMs) Derived from Naturally Occurring Phenolic Monoterpenoids. Med chem (Los Angeles) 6: 123-128. doi:10.4172/21610444.1000336

case of antioxidant activity; Carvacryl Diindolyl methane (CDIM) and Eugenyl Diindolyl methane (EDIM) showed notable $\mathrm{IC}_{50}$, while in $\alpha$-amylase inhibitory activity, Thymyl Diindolyl methane (TDIM) exhibited prominent $\mathrm{IC}_{50}$ values.

\section{Acknowledgements}

We are grateful to UGC SAP, (New Delhi) for financial assistance to our research projects at present times.

\section{References}

1. McDougal A, Gupta MS, Ramamoorthy K, Sun G, Safe SH (2000) Inhibition of carcinogen-induced rat mammary tumor growth and other estrogen-dependent responses by symmetrical dihalo-substituted analogs of diindolylmethane. Cancer letters 151: 169-179.

2. Fahy E, Potts BC, Faulkner DJ, Smith K (1991) 6-Bromotryptamine derivatives from the Gulf of California tunicate Didemnumcandidum. Journal of natural products 54: 564-569.

3. Osawa T, Namiki M (1983) Structure elucidation of streptindole, a novel genotoxic metabolite isolated from intestinal bacteria. Tetrahedron letters 24 : 4719-4722.

4. Bharate SB, Bharate JB, Khan SI, Tekwani BL, Jacob MR, et al. (2013) Discovery of $3,3^{\prime}$-diindolylmethanes as potent antileishmanial agents. Eur J Med Chem 63: 435-443.

5. Sharma DK, Rah B, Lambu MR, Hussain A, Yousuf SK, et al. (2012) Design and synthesis of novel N, N'-glycoside derivatives of 3,3'-diindolylmethanes as potential antiproliferative agents. Med Chem Comm 3: 1082-1091.

6. Bandgar BP, Shaikh KA (2003) Molecular iodine-catalyzed efficient and highly rapid synthesis of bis (indolyl) methanes under mild conditions. Tetrahedron letters 44: 1959-1961.

7. Ji SJ, Wang SY, Zhang Y, Loh TP (2004) Facile synthesis of bis (indolyl) methanes using catalytic amount of iodine at room temperature under solventfree conditions. Tetrahedron 60: 2051-2055

8. Deb ML, Bhuyan PJ (2006) An efficient and clean synthesis of bis (indolyl) methanes in a protic solvent at room temperature. Tetrahedron Letters 47 : 1441-1443.

9. Ji SJ, Zhou MF, Gu DG, Jiang ZQ, Loh TP (2004) Efficient Felll-catalyzed synthesis of bis (indolyl) methanes in ionic liquids. European Journal of Organic Chemistry 7: 1584-158.

10. Li JT, Dai HG, Xu WZ, Li TS (2006) An efficient and practical synthesis of bis(indolyl)methanes catalyzed by aminosulfonic acid under ultrasound. Ultrason Sonochem 13: 24-27.

11. Hasaninejad A, Shekouhy M, Zare A, Ghattali SH, Golzar N (2011) PEG-
$\mathrm{SO} 3 \mathrm{H}$ as a new, highly efficient and homogeneous polymeric catalyst for the synthesis of bis (indolyl) methanes and 4,4'-(arylmethylene)-bis (3-methyl-1phenyl-1Hpyrazol-5-ol)s in water. Journal of the Iranian Chemical Society 8: 411-423.

12. Rahimizadeh M, Bakhtiarpoor Z, Eshghi H, Pordel M, Rajabzadeh G (2009) TiO2 nanoparticles: an efficient heterogeneous catalyst for synthesis of bis (indolyl) methanes under solvent-free conditions. MonatsheftefürChemieChemical Monthly 140: 1465-1469.

13. Kamble S, Rashinkar G, Kumbhar A, Salunkhe R (2012) Hydrotrope induced catalysis in water: a clean and green approach for the synthesis of medicinally relevant bis (indolyl) methanes and 2-aryl benzimidazoles. Synthetic Communications 42: 756-766.

14. Tepe B, Daferera D, Sokmen M, Polissiou M, Sokmen A (2004) In vitro antimicrobial and antioxidant activities of the essential oils and various extracts of Thymus eigii M. Zohary et PH Davis. J Agric Food Chem 52: 1132-1137.

15. Prakash P, Gupta N (2005) Therapeutic uses of Ocimum sanctum Linn (Tulsi) with a note on eugenol and its pharmacological actions: a short review. Indian J Physiol Pharmacol 49: 125-131.

16. Deighton N, Glidewell SM, Deans SG, Goodman BA (1993) Identification by EPR spectroscopy of carvacrol and thymol as the major sources of free radicals in the oxidation of plant essential oils. Journal of the Science of Food and Agriculture 63: 221-225.

17. Thakur K, Pitre KS (2007) Modified electrochemical methods for the determination of eugenol in clove (Syzygium aromaticum) and pharmaceutical formulations. Reviews in Analytical Chemistry 26: 199-208.

18. Mastelic J, Jerkovic I, Blazevic I, Poljak-Blazi M, Borovic S, et al. (2008) Comparative study on the antioxidant and biological activities of carvacrol, thymol, and eugenol derivatives. J Agric Food Chem 56: 3989-3996.

19. Rubió L, Motilva MJ, Romero MP (2013) Recent advances in biologically active compounds in herbs and spices: a review of the most effective antioxidant and anti-inflammatory active principles. Critical reviews in food science and nutrition 53: 943-953.

20. Wynberg H (1960) The Reimer-Tiemann Reaction. Chemical Reviews 60 169-184.

21. Vichai V, Kirtikara K (2006) Sulforhodamine B colorimetric assay for cytotoxicity screening. Nat Protoc 1: 1112-1116.

22. Son S, Lewis BA (2002) Free radical scavenging and antioxidative activity of caffeic acid amide and ester analogues: structure-activity relationship. Journal of agricultural and food chemistry 50: 468-472.

23. Akhter F, Hashim A, Khan MS, Ahmad S, Iqbal D, et al. (2013) Antioxidant, a-amylase inhibitory and oxidative DNA damage protective property of Boerhaavia diffusa (Linn.) root. South African Journal of Botany 88: 265-272. 